André Brink

\title{
Woman and language in darkest Africa: The quest for articulation in two postcolonial novels
}

\begin{abstract}
The paper focuses on issues raised by Conrad's Hean of Darkness and on ways in which two recent novels, The Expedition to the Baobab Tree (Slockenström) and The Whales in Lake Tanganyika (Hagerfors) employ the same model of the joumey of exploration in order to break down phallo- and eurocentric concepts of language in an attenpt to amive at a new articulation of Africa. In Heart of Darkness Marlow crosses the limits of language in his confrontation with the Other (Kurtz, and Africa, both of which have a female dimension) and has to invem a 'new' language, post facto, to explain his discovery to the Woman who awaits him at the other end. In the Stockenstrom text, the narrator and central personage is already female, but she is illiterate; and in order to articulate her body, in which her joumey is subsumed, an inplied namalor may have to narrate on her behalf, in a language which first has to liberate itself from the processes of bondage and appropriation to which the slave woman has been subjected all her life. In The Whales in Lake Tanganyika an intertext arises from the dialogue of this narrative with H.M. Stanley's historical journal; and this projects the diarist Shaw as the deconstructor of male and European dichotomies. Shedding conventional language, linearity and 'reality', his diary becomes the translation of an inaccessible 'new' language which is the only way in which Spivak's 'subaltent' can attain speech to articulate the femininity implicit in Africa.
\end{abstract}

\section{Introduction}

Suspect as Heart of Darkness may have become in some circles, Joseph Conrad's articulation of African otherness still appears to underlie many postmodern, and specifically postcolonial, narrative explorations of the continent. In this paper I propose to focus on issues raised by Conrad and on some of the ways in which two recent novels, The Expedition to the Baobab Tree by Wilma Stockenström (1983) ${ }^{1}$ and The Whales in Lake Tanganyika by Lennart Hagerfors (1991), ${ }^{2}$ employ the model of the quest or the journey of exploration in order to break down phallo- and eurocentric concepts of language and narrative in an attempt to arrive at a new articulation of Africa.

1 Translated from Afrikaans by J. M. Coctzec. Original Afrikaans edition Dic kremetartekspedisie, published by Human \& Rousseau, Cape Town etc, 1981.

2 Translated from Swedish by Anselmo Hollo. Quotations are from the Penguin cdition of 1991. First published in English by André Deutsch, London, 1989. Original Swedish edition Valarna $i$ Tanganyika, Stockholm, P. A. Norstedı \& Söners, 1985. 


\section{Language and darkness}

In Heart of Darkness, Marlow's expedition in search of Kurtz is, of course, not so much a probing of an African or geographical terra incognita as of human darkness. From the very beginning of the novel the 'interminable waterway' of the Thames is enveloped in darkness: "The air was dark above Gravesend, and farther back still seemed condensed into a mournful gloom" (p. 27) - a gloom to which, in the completion of the narrative's circular sweep, the end returns:

The offing was barred by a black bank of clouds, and the tranquil waterway leading to the uttermost ends of the earth nowed sombre under an overcast sky - seemed to lead into the heart of an immense darkness. (p. 121.)

In fact, the whole history of the world, presented as a story of violent conquest and imperial greed, becomes an interminable displacement of the locus of darkness ("'And this also,' said Marlow suddenly, 'has been one of the dark places of the earth"', p. 29).

Within this larger darkness the search for Kurtz, the being without a centre, the open signifier, the hollow man avant la lettre, becomes a process of self-discovery, a probing of inner darkness.

Africa itself has no predetermined or objective qualities: it can be either "evil or truth" (p. 52) - and although, as the expedition proceeds, the intimation of "hidden evil" tends to predominate (p. 65), this is a perception rather than an attribute. But should this be read as another empty signifier or, rather, as a marker of the limit of language? More and more, as the text unfolds, the reader is confronted with what cannot be said in (conventional, or European) language. Darkness itself is the obvious metaphor of the unsayable, of that territory which can only be invaded by language post facto, i.e. in Marlow's retrospective narrative. "The most you can hope from (life) is some knowledge of yourself - that comes too late - a crop of inextinguishable regrets" (p. 112). Language, here, fulfils the role played by suffering in the Léon Bloy epigraph to Graham Greene's The End of the Affair: "Man has places in his heart which do not yet exist, and into them enters suffering in order that they may have existence."

Not that this post-facto language is to be trusted: Marlow's entire account, after all, ends in the lie he tells to the bearer of the ultimate darkness of the narrative, the woman "all in black" (p. 117), to whom he offers his falsehood as a "great and saving illusion that shone with an unearthly glow in the darkness, in the triumphant darkness from which I could not have defended her - from which I could not even defend myself" (p. 119). We find ourselves within that lie which, as Eco has defined it, is the very condition of language: "...(S)emiotics is in principle the discipline studying everything which can be used in order to lie" (Eco, 1979:7). Language marks, for Marlow, the point where history is transformed into story. ${ }^{3}$ And this is both confirmed and compounded by his retelling of the story to his interpellants in the text, and by extension to the (real and/or implied) readers of Conrad's text.

\footnotetext{
${ }^{3}$ The argument about history being itself a text need not be pursued here: it is certainly not part of Conrad's discourse.
} 
This movement begins much earlier in the novel. Marlow's entire expedition along the river into 'the heart of Darkness' represented by Africa charts not only geography but stages and territories of communicability. From more or less familiar, more or less 'civilised' outposts of empire, characterised by the possibilities of mercantile barter and linguistic exchange, the expedition moves into a region of silence marked only by the unintelligible roll of drums (which, like those in the Hagerfors text, may 'mean' anything: "war, peace, or prayer", p. 68). "The bush around said nothing" (p. 71). The entire powerplay invested in language becomes irrelevant:

(I)t occurred to me that my speech or my silence, indeed any action of mine, would be a mere futility.

What did it matter what anyone knew or ignored? What did it matter who was manager? (p. 72 .)

When speech and silence become equivalent there is indeed a breakdown of all the categories that used to define language or make it necessary, even possible.

This is confirmed by the death of the helmsman on Marlow's boat:

We two whites stood over him, and his lustrous and inquiring glance enveloped us both. I declare it looked as though he would presently put to us some question in an underst andable language; but he dicd without uttering a sound. (p. 82.)

What makes this moment so decisive to Marlow is that it seems to him to signal the end of all hope of communicating with Kurtz: that is, the end of the hope of finding a language in which the mystery/darkness of Kurtz's existence may be rendered intelligible. It is worth while looking attentively at the passage following the death of the helmsman:

I couldn't have been more disgusted if I had travelled all this way for the sole purpose of talking with Mr Kurtz. Talking with ... I flung one shoe overboard, and became aware that that was exactly what I had been looking forward to - a talk with Kurtz. I made the strange discovery that I had never imagined him as doing, you know, but as discoursing. I didn't say to myself, "Now I will never sec him," or "Now I will never shake him by the hand," but, "Now I will never hear him." The man presented himself as a voice (...) The point was in his being a gifted creature, and that of all his gifts the one that stood out pre-eminently, that carried with it a sense of real presence, was his ability to talk, his words - the gift of expression, the bewildering, illuminating, the most exalted and the most contemptible, the pulsating stream of light, or the deccitful flow from the heart of an impenetrable darkness. (p. 83.)

Is this not a key to that most urgent problematic of postcolonial writing: "... the question of how the third-world subject is represented within Western discourse" (Spivak, 1988:271), the confusion of "Them as Us", i.e. "the special post-colonial crisis of identity" (Ashcroft, et al. 1989:8-9), the difficulties and dangers of "taming the subject" raised by the question, "Can the Subaltern Speak?" (Spivak, 1988:306). Kurtz is of course not a 'subaltern' in the Spivakian sense, but inasmuch as he is - among many other things - an image of the 'mystery', the 'darkness' of the continent, he represents at least the problem of language raised by an encounter with Africa. As the language of the empire loses its coherence, and in fact its validity, the need for a new language becomes imperative (all the more so, and specifically, since the very notion of an 'imperative' is determined by the existence of an imperium). And this new language is, most disconcertingly, both a 'pulsating stream of light' and an emanation from 'impenetrable darkness'. Perhaps the key to such a new language lies in its faculty of dispensing with an entire mode of thinking encapsulated in either/or. And the very 'obfuscation' and 'diffuseness' and 'vague generalisation' of which a generation of critics since Leavis has accused Conrad may demonstrate the extent to 
which the ready-made, conventional, eurocentric, male language of the Great Tradition is simply not adequate to give literary substance to Africa.

Very soon after this crucial point in the narrative the chronological flow which has characterised it so far is interrupted. But it goes far beyond chronology: at the very moment when the reader is brought to the threshold of a confrontation with Kurtz himself that is, at the point when the 'heart' of the story's 'darkness' is expected to move into focus not only the story, but grammar itself, breaks down:

\begin{abstract}
I was cut to the quick at the idea of having lost the inestimable privilege of listening to the gifted Kurtz. Of course I was wrong. The privilege was waiting for me. Oh, yes, I heard more than enough. And I was right too. A voice. He was very little more than a voice. And I heard - him - it - this voice - other voices - all of them were so little more than voices - and the memory of that lime itself lingers around me, impalpable, like a dying vibration of one immense jabber, silly, atrocious, sordid, savage, or simply mean, without any kind of sense. Voices, voices - even the girl herself - now - (p. 84).
\end{abstract}

The grand rhetorical gesture ("inestimable privilege", "impalpable", "dying vibration") soon falters as the narrator resorts desperately to one inadequate adjective after the other ("silly", "atrocious", "sordid", "savage", "mean"); the syntax becomes disjointed and the semantic load of the sentence grows unmanageable. And in the incoherent jabbering of the last words we encounter a wholly unexpected figure who has not yet surfaced in the text but who is to become both 'the heart of the matter' and 'the end of the affair': 'the girl herself'.

A moment later she is multiplied:

Girl! What? Did I mention a girl? Oh, she is out of it - completely. They - the women I mcan - are out of it - should be out of it. (p. 84.)

And so indeed they should, in this all-male world of explorers and narrators.

(In its "making sense" of the world, narrative endlessly reconstructs it as a two-character drama in which the human person creates and recreates himself out of an abstract or purcly symbolic Other the womb, the earth, the grave, the woman (...) The drama has the movement of a passage, a crossing, an actively experienced transformation of the human being into - man: De Lauretis 1984:121.)

\title{
2.1 Woman: destination of the quest
}

But the point is precisely that woman is not 'out of it': she is not only subsumed in the quest, but becomes its destination (Kurtz's fiancee to whom the ultimate report is transmitted and the ultimate lie is told) and its definition (the triumphant and heraldic woman who appears to the visitors as they leave on the steamer) ${ }^{4}$

And the crucial function of the female figure (however embarrassingly stereotyped and male-orientated Marlow's view of that 'savage and superb, wild-eyed and magnificent' earth-mother may be, p. 101) is revealed through that Black Hole in the text where chronology and language falter. It is a silence and a void which can only be filled retroactively, in the act of language inventing it.

\footnotetext{
4 She also looms over the beginning of Marlow's journey, of course, both in the shape of the two women "guarding the door of Darkness, knitting black wool" (p. 31) and in the shape of the aunt who confirms (to the archetypal male) the (archetypal female) "world of their own" (p. 39), to anticipate all the notions of Otherness in the text.
} 
As in Atwood's Surfacing (1983), where the narrator moves wholly beyond language in the narrative only to return to it in her narration of the unsayable (the reader would have no intimation of her experience whatsoever had it not erupted into language), the last third of Marlow's narrative is an attempt to define what has happened at that point of confrontation with the unspeakable. On the surface, after the descent into "strings of amazing words that resembled no sounds of human language" (p. 109), after the ultimate failure of communication ("The horror! The horror!", p. 111), the newly invented language may appear ordinary enough:

They were common cveryday words - the familiar, vague sounds exchanged on cvery waking day of life. But what of that? They had behind them, to my mind, the terrific suggestiveness of words heard in drcams, of phrases spoken in nightmares. (p. 108.)

This is vital to an understanding of what Africa may have to say when one day it does break into speech: just as there is no 'female sentence' essentially different from male syntax, the postcolonial language of the subaltern can hardly be expected to differ 'in essence' from that of empire. Their differences are experiential, processional, contextual, not essential.

The straight male line of Marlow's expedition along the river becomes not only an aller/retour but a transcendence of linearity: it leads him, by a commodus vicus, back to its own beginning (designing not so much a circle as a spiral); and it leads ever inward toward that darkness where Self and Other are indistinguishable.

And the 'point' of both these motions is Woman. One of the most significant aspects of the novel is that Kurtz himself is equated, through the workings of an ancient European memory, with "an enchanted princess sleeping in a fabulous castle" (p. 77). In one sense this woman is, typically, the 'witch', Mother Africa, relegated to the periphery by/in a male world which can only 'accommodate' or 'manage' her by defining her radical alterity as 'savage' (that is, simultaneously 'fecund' and 'mysterious'). In another she is the ethereal being to whom men must justify their exploits, "one of those creatures that are not the playthings of Time" (p. 117). In the final analysis, it is she who compels Marlow to bestow meaning on experience - even if, as we have seen, that meaning is an invention and a lie ("The last word he pronounced was - your name", p. 121). Without her compulsion there could have been no language and no narrative. Woman here becomes more than a catalyst, more than "an element of plot-space, a topos, a resistance, matrix and matter" (De Lauretis, 1984:119): she becomes the condition of meaning.

\section{The interior journey and the exploration of language}

In The Expedition to the Baobab Tree both author and narrator are female. In a strictly realistic sense, the anonymous slave woman who spends her last days in the bole of a baobab recounting her life has indeed undertaken an exhausting journey across the face of Africa; but in another sense it is impossible ontologically to divorce her from her history. She is her story; her body is the journey of her life, scarred with the marks of masters and lovers, with suffering and exposure, with meagre indulgence and scant joy. She is Africa. But for the reader to comprehend her, she must also become language. 
From the beginning it is clear that her narrative is not the chronological account of a linear journey. Her master/lover, it is true, conceives of the journey in realistic terms, "wanting to prove that an overland route ought to exist" (p. 46); and, true to the De Lauretis model, he identifies 'journey' with 'story': "I shall have to live the story out to its end, he decided. All stories end", p. 74. But to the slave woman the journey is interiorised from the outset: "We departed for the frontiers of the spirit" (p. 60)..$^{5}$ This means "travelling in circles around one place" (p. 9), "an endless roundabout circle" (p. 66). If the baobab is, in one sense, the destination of her physical journey, it is at the same time the starting point from which she sets out on endless new journeys of (re)discovery and (re)definition: "Reborn every time from the belly of a baobab, I stand full of myself" (p. 14). The baobab is Woman; it is the Imaginary Order; hence it is everything language is not.

This is the most important paradox of the text: if the narrator has returned from the Symbolic Order of the male (the successive masters who bought and used and loved her) to the Imaginary and to the Womb of the baobab, she can only explain and interpret it in the terms of the very language she has had to shed in order to make such a return possible. Ideologically, it represents - as does Marlow's attempt to narrate, in language, his encounter with Kurtz which took place beyond language - the problem of postcolonial fiction in general: the need to 'say' the self in the language of the 'other' (and indeed vice versa); the need to invent both self and other without appropriating either - "not simply by reversing the hierarchical order, but by interrogating the philosophical assumptions on which that order was based" (Ashcroft et al., 1989:33).

In Heart of Darkness Marlow's narration is framed by the sailor who relays to an external reader what has previously been conveyed to the sailor: the narratorial frame guarantees credibility and vraisemblance. But in The Expedition to the Baobab Tree there is, at first sight, no suggestion of mediation between the slave woman and the reader who apparently eavesdrops on the narrator's private (and in fact unspoken) thoughts. "Woman, in other words," says Moi (1985:114), "is wholly and physically present in her voice - and writing is no more than an extension of this self-identical prolongation of the speech act."

There is, however, a problem. This woman herself cannot write. ("If I could write," she admits on p. 30, "I would take up a porcupine quill and scratch your enormous belly full from top to bottom (...) Big letters. Small letters. In script full of lobes and curls, in circumambient lines I write round and round you, for I have so much to tell of a trip to a new horizon that became an expedition to a tree. Here comes a rhythmic pause.") This writing would be everything conventional writing is not, as far beyond the linear and the logocentric as her journey has transcended geography. And yet the reader can follow her thoughts! Because these thoughts have been transferred, by an invisible mediator, an implied narrator, to a page, translated into a language intelligible to the reader (and the choice of the 'language of the oppressor' featuring in Stockenström's original Afrikaans text is doubly significant). At every moment in the narration, in other words (quite literally 'in

\footnotetext{
5 An interesting starting point for an exploration of the text would be Atwood's fascinating if contentious notion that "every country or culture has a single unifying and informing symbol at its core" (Atwood, 1972:31). The symbol she assigns to the United States is 'The Fronticr', to Britain 'The Island', to Canada 'Survival'. In the case of South African literature, if one were to indulge in a game with such absolutist and essentialist overtones, either 'The Horizon' or 'Taming' might yicld intcresting results - certainly for The Joumey to the Baobab Tree.
} 
other words'), there is an invisible but crucial battle waged between the language of appropriation and the language appropriated 6 - which, in itself, replicates another struggle in the text, between patriarchy and femininity, master and slave. This would be the ultimate irony in such a reading of the text: that only by enslaving in language the woman recently liberated from bondage can she be made intelligible to the reader. In more ways than one "the postcolonial text is itself a site of struggle for linguistic control" (Ashcroft $e t$ al., 1989:115).

\subsection{The struggle to articulate the 'own' language}

In the early stages of the narration it still appears possible to follow the narrator's account of the slave woman's own conscious struggle with language. We learn about the language of her youth, prior to her capture and enslavement - a language which at least attempts to re-present a lost Imaginary Order, to which the woman will return at the end of her circle. Surrounded by the 'little people' (San?) who tend and worship her during her last days before they supply her with the poison which offers her the choice of death, she registers that, "I hear the click of the sounds they utter, I mutter something to myself that sounds like the language of my childhood days. Words that had got lost take on dim shape" (p. 99). This is followed (even if chronology exists only in the reader's reconstruction of the narrative) by the acquisition of the master's language: or, more precisely, the acquisition of the different languages spoken by successive masters. (Every time, "it is almost as if I were learning again to talk," p. 28.) In this text, the learning of the master tongue coincides with the accession to the Symbolic Order of the (incestuous) Father. "In his language I whispered lewd stories which made him smile blissfully in my arms" (p. 20).

It is significant that on this level language is inextricably linked with 'story': this kind of story, like that employed by the slaves to dream of freedom (p. 24), or by the woman to interpret her fantasy world (p. 72-73), or by the Stranger to cast the spell of his worldly experience over his demure listener (p. 102), replicates the power-play of a society based on slavery and on possessions; and it anticipates this story the reader is holding in his/her own hands at the time of reading; so that, by extension, the processes of acquisition and appropriation continue beyond the physicality of the text.

The kind of language the slave woman encounters (and adopts) in the society of her masters is linked to that spoken by her second master's parrot: "He turned language inside out so that the meaning fell out and nothing could be said" (p. 31), as well as to the attempts of the apes in the wilderness to transcend "the limits of their animal nature" in order to "address me on my level" (p. 31), which again brings into focus this text's attempt to go beyond the 'limits' of the woman's slave nature in order to address the reader on his/her level.

It is always "their language": a language to be spoken "with authority" (p. 76). And in opposition to it there exists the slave woman's 'own': "My tongue is meant for me, my tongue, my mouth, my whole self is mine" (p. 27).

\footnotetext{
${ }^{6}$ Could this be resolved by assuming that the voice of the implied narrator coincides with that of the author and thereby is invested with 'female idenlity'? Of course, "to be signed with a woman's name doesn't necessarily make a piece of writing feminine" (Cixous, 1981:52); on the other hand, the voice of the individual woman is often held to incarnate "the first voice of love which all women preserve
} 
But in order to live into this language of her own, different from that of her masters, or of her fellow workers, or of the little people, she first has to shed that early language of the Symbolic Order. On the expedition from east/west (which in itself suggests a return to origins, a retracing of her steps to where she first came from) she stops talking to the bearers and the other slaves in the group (pp. 71, 85); soon, only "tatters of speech" (p. 75) remain. The very earth becomes a tabula rasa (p. 90), awaiting inscription, not by 'language', but at most by Derridean 'traces'. The very notion of language is transformed into an elemental happening:

It is all meaningless, I thought, and walked off and descended the koppie alone, I went as far as a jutting rock, and as I stood there I heard myself say something. Not say. Mumble. Stammer. I heard the words fall from my mouth in snatches over the cliff to be swallowed by the windfilled silence, words that spoke of a jackal that would run through the air with a burning tail and set all the air afire. So there sprang a jackal from my mouth. I heard myself prophesy feverishly of languages that yet slept, of strange trees that would one day march out through valleys and over hills and along mountain-sides ...

"Not say. Mumble. Stammer": in Heart of Darkness, one recalls, the confrontation with Africa ("this land, this river, this jungle, the very arch of this blazing sky (...) so hopeless and so dark, impenetrable to human thought", p. 94) resulted in a similar breakdown of language, "one immense jabber, silly, atrocious, sordid, savage, or simply mean, without any kind of sense" (p. 84) and in the apprehension of something beyond its conventional frontiers.

And the only resolution lies in the assumption of a full feminine identity: woman becomes tree becomes Africa, inverting all traditional (male) values:

I dive into dark water and row with my wings toward the far side where in descending silence I am no longer able to help myself and deafly fly further and further. I will find rest in the upside-down. I fold my wings. (p. 111.) ${ }^{8}$

\section{Language and different responses to Africa}

The narrative situation in The Whales in Lake Tanganyika is determined by the way in which the diary of the explorer Shaw presents itself in a very specific intertextual relationship with his leader Stanley's famous journal, published as How I Found Livingstone (1872).

alive" (Cixous, quoted in Moi, 1984:114).

${ }^{7}$ This is followed, on p. 98 , by another vision of an apocalyptic 'language beyond language':

"Suddenly I knew that if I were now to speak, something tremendous would happen. The dead would arise, or no, they would become visible to me, and time would somersault, the earth would tilt, capsize, and hang upside down in the direction of limitless darkness and the spirit of the water would voyage into eternal space and forever be lost."

In respect of the 'visionary' aspects of the passage it anticipates The Whales in Lake Tanganyika; in respect of the choice of non-visionary, 'vague' phrases like "something tremendous", "limitless darkness", "eternal space", "forever (...) lost", the resonance with Heart of Darkness is obvious.

${ }^{8}$ This also concludes the water imagery in the text. And we know that, "(f)or Cixous, as for countless mythologies, water is the feminine clement par excellence" (Moi, 1985:117). 
By his own account, the historical Stanley is the archetypal white male explorer/narrator: the one who penetrates virgin territory, traverses it in a process of linear and chronological progression, subdues and tames it (with violence, if necessary), maps and charts and ultimately appropriates it through naming and description. He is the "hero as mover of the narrative, the center and term of reference of consciousness and desire" (De Lauretis, 1984:112); if on his way he uses/abuses whatever native female happens to become available, his real Other is - as it is, largely, for Marlow - the land itself, the "femaleobstacle-boundary-space" described by De Lauretis (1984:121).

The interaction between the texts of history (Stanley's journal) and story (Shaw's narrative in The Whales in Lake Tanganyika) is signalled in Hagerfors's novel on p. 91 where Shaw confesses: "I have sneaked an illicit look at Stanley's notes", which is reciprocated on p. 145:

Stanley wants to get at my notes. He asked me if he could see them, and 1 said no. He told me it was an order, and I ate the piece of paper he was pointing at. One by one, the words dropped into my stomach. It was an entertaining fecling.

The instruction is clear: neither text can be read without the other.

Now it is significant that, in the historical text, Stanley is extremely disparaging of the man he hired in Zanzibar to accompany him to Lake Tanganyika in an attempt to find the missing missionary-explorer Livingstone. What concerns us at the moment is not in the first place his contemptuous references to Shaw as a "sentimental driveller", as introspective, or as insufferably indolent, but the remark that his subaltern is "so ignorant of penmanship as scarcely to be able to write his own name" (Stanley, 1872:305, my italics).

The Shaw of the Hagerfors text, however, is a highly sensitive manipulator of the pen and of language. The whole text, in fact, exists solely by virtue of - and by the virtuosity of - his penmanship. This 'discrepancy' will be refurned to later as crucial to our enquiry.

The novel as a whole may be approached as a study in different responses to Africa, and to the Other. Stanley's first intrusion into Shaw's life is marked by his "hard metallic voice" which cuts through all other sounds "like a knife" (Hagerfors, 1991:3); his moral guide throughout the expedition is his consciousness of his race and his sex ("We white men bear a great responsibility", p. 27); ${ }^{9}$ he "solves" most problems either with his whip or his gun (pp. 35, 50 etc.); even his speech is a mere prelude to action ("For him, talk without action was like eating without swallowing your food," p. 29); and "to him the world is just a map to draw lines on" (p. 128).

Shaw himself is infected by the example of his leader: upon occasion he consents, albeit unwillingly, to punish his underlings ("I am a kind man. I am not used to handling whips. But anyone who mocks me or disobeys me will get a bullet through his skull," p. 31); and after his horror upon first witnessing some of the men raping a passing girl (pp. 58-59), he has little compunction about later doing the same (p. 125). But his proclivities impel him in a different direction. His approach is that of an artist: he plays the accordion (p. 4, etc.); he derives aesthetic satisfaction from the woodcarving Saburi and Asmani offer him (p. 43);

\footnotetext{
9 The historical Stanlcy (1872:315) provides the basis for it: "'Don't back out, man, before these Arabs; remember you are a whitc man."
} 
he sees a landscape as "sketched in pencil" (p. 57), and the "plains and forests put (him) in a trancelike state" (p. 51); above all, deprived of a mirror in which he might observe the world and himself, he writes this text.

\subsection{Identification with Africa: the 'unlearning' of the language of habit}

Of course one should never forget that if this subaltern speaks/writes, he still does so as a European, a stranger to Africa, not a native, not one of the colonised. There is indeed "a gap which opens between the experience of place and the language available to describe it" (Ashcroft et al., 1989:9). On the other hand, the process of identification with Africa which involves 'unlearning' the language of habit and of the metropolis in order to learn another 'language' as far beyond the Symbolic Order as that of Stockenström's slave woman - goes incomparably further than that of Heart of Darkness. And in his reactions he is the antithesis of Stanley.

To Stanley, teleology is all. Even if he pretends, in the beginning, that "an explorer never knows in advance what he will discover" (p. 8), he knows exactly where he is heading for (Lake Tanganyika), the route he will follow to get there (from Bagamoyo to Simbamwenni, to Makata, Kiora, Mpwapwa, Tabora and then Ujiji), and what he aims to find ("the purpose of the entire expedition was to find and assist Livingstone", p. 148). To Shaw, neither the purpose nor the trajectory of the journey is predictable ("Often I wonder what my actual role is in this expedition, as I don't fulfil any visible function", p. 72); its meaning evaporates in absurdity ("I have never seen more clearly, understood more deeply. There is nothing to understand", p. 77); and very soon even chronology - the one set of data a diarist may be expected to cling to! - becomes haphazard ("I have no idea of the chronology of events", p. 66; "Now my days are a blur", p. 78). Towards the end, in the crucial scene where the "captain of the guard", Bombay, accompanies him in a profound sexual experience, all signs of linearity are effaced: "There are details of an almost painful clarity, but the narrative is disrupted by gaps in memory and inexplicable episodes" (p. 132).

Both in the "gaps" and in the intrusion of dreamlike or surreal sequences ("inexplicable episodes") Shaw's narrative resembles that of Stockenström's slave woman; and in both cases these may be seen to break down patriarchal/imperialistic hierarchies and linearities of narrative in order to approach more closely the female otherness of Africa. That is to say, both these strategies are to be read in function of the expedition beyond the frontiers of the 'old' language.

\subsection{Approaching "the womb of Africa" - in language}

The very first action recorded in Shaw's diary is the contract to accompany Stanley's expedition into the interior: it is a commitment both in and to language ("Without reading what it said, I wrote my name in the big damp stain his finger had left there," p. 9); and on p. 25 his colleague Farquhar confirms that "We've signed our lives away."

On their trek they move through landscapes which are silent, i.e. devoid of language (pp. $69,90,149$, etc.); and when they encounter strangers their languages are incomprehensible 
(pp. 51, 86, etc.) - all of which defines Shaw's increasing isolation and alienation. As early as pp. 16-17 there is this Conradian passage:

This will be all for now - but writing consoles me. Outside my shabby house, the African night stands dense and dark, full of stale, salty air (...) Out there - out there - past forests, savannahs, and mountains, the greater darkness is waiting. It is inhabited, in a tight, magical, physically close community, by Negroes who have never seen the ocean. I don't belong there.

It is significant that the difference between the familiar and the strange is identified with the dichotomy land/sea. As a sailor, Shaw is 'at home' on the sea; he is only 'at sea' on dry land. And as the expedition proceeds (towards Lake Tanganyika, "the womb of Africa", p. 162), it becomes more and more a (re)discovery of female water within the hard male continent; it leads to a reconciliation of the man Shaw with the female in himself. ("I am the sea. I am the ship that carries the sea with it across the continent of Africa," p. 144.) And that his most precious possession on the journey should be "a carving of a female figure, pregnant, with a big smooth belly" (p. 43), ${ }^{10}$ comes as no surprise. The figurine is also linked specifically, and almost too explicitly, to the great sea-creatures, the whales, whose code informs the narration. "Will I ever again see a whale? I have to be content with the small female figurine. I think that in some strange fashion it has caused me to remember the whales" (p. 45).

As conventional language begins to recede from Shaw (even though, as diarist, as narrator, he can never abandon it and must remain as desperately linked to it, and determined by it, as Atwood's narrator in Surfacing), so, as we have noted above and as we would expect, do chronology and linearity. So, too, does history, as it merges with myth. Behind the surface chronology of historical events - the progress of the expedition, the war against Mirambo, meeting Livingstone, all the events also recorded in Stanley's journal - we witness, as in The Expedition to the Baobab Tree, the weave of myth: Bombay's love; dream sequences; hallucinations; the events experienced by the expedition after Shaw has left it (i.e. the whole of the final chapter, 'Outside'); the stories of the Africans themselves:

One day, the birds will fall to the ground. The rivers will stop running, and two suns will rise in the sky, one from the cast and one from the west... (p. 52).

This leads one to a reassessment of Shaw's diary itself. We have noted that, if the historical personage Stanley is to be believed, Shaw can hardly write his own name - a far cry from the textual density of The Whales in Lake Tanganyika. It may be read as a way of showing up Stanley as a liar, or of emphasising the differences between the two men. Another possibility would be to read it as I have read the Stockenström text above, as the narrative of an implied narrator. But there is another possibility, which retroactively would also liberate a fascinating new set of meanings in The Expedition to the Baobab Tree, and that would be to take the historical Stanley at his word and accept that Shaw is a near-illiterate. In this case his diary may be read, as it were, as a 'translation' from another 'language' altogether - not from the 'original Swedish' but from a 'language' we do not have direct access to. (Even the original Swedish text should then be read as a translation from this language-beyond-language.)

10 Towards the end of the journey he offers it to Farquhar as a parting gift; but he can only part with it - and even so it smarts - because by then the process of reconciling himself with the female in himself, and in Africa, is already far advanced. 
In a passage quoted above we have already noted Shaw's early affirmation that 'writing consoles me' which is, at most, a crude approximation of what, at that early stage, he cannot yet formulate because he has not yet acceded to the 'other language' and still has to make do with the conventions and grammar of the old (male, imperialist) system.

A process of transition from the one to the other is suggested on p. 91, where Shaw, having sneaked his 'illicit look at Stanley's notes', comments that an episode regarded as particularly traumatic by himself hardly merits a mention in Stanley's journal: "He says simply that the dog and a few porters died in the Makata swamp". But this is a lie! The reader who consults the historical Stanley $(1872,141-142$; i.e. the 'notes' Shaw himself ostensibly looked at) will find there a quite extensive, if dramatically different, account of the episode. What we have here, I would propose, is not so much the time-honoured modernist process of relativism, a strategy of casting doubt on Stanley's veracity (and, reciprocally, on Shaw's own) as a much more radical strategy to place language itself under suspicion and at risk. It marks decisively the transition from the 'old' language to the 'new'. Soon it debouches in this illuminating passage:

I want my writing to be heavy, like the drums at night, like when the soldiers throw a live pig onto the butchering block, heavy as the shade of the mango tree. But the words are pulverized, diluted, turned into gas. First they become light and opaque like the morning fog. Then, as the warmth of the sun cautiously advances its tongue, they dissolve without resistance. (p. 110.)

A mere two paragraphs later the new startling consciousness dawns: "I record in order to erase. Writing is the most exact instrument for forgetting" (p. 111).

\subsection{Language as the "written counterpart of the unwritten world"}

The language theory at work here accords with Calvino's in If On a Winter's Night a Traveller: the more language erases the world, the more it foregrounds itself as "the written counterpart of the unwritten world" (Calvino, 1981:172). Every word on the page is written only by virtue of what cannot be written. The said has value only in function of the nonsaid, the non-sayable. And this opens tremendous perspectives into postcolonial writing in general.

From this moment on, throughout the chapters vaguely entitled 'The Interior' and 'Outside' (in which an absence of naming succeeds the precise notation of place in the earlier chapters), nothing is 'recorded' any more; there is no longer the assumption of a relation between a (prior) event and its (subsequent) recording, which constitutes the standard contract of journal/diary/autobiography. Inscape succeeds landscape; language itself becomes the 'subject' and the 'event' of the narrative. Previously, Shaw often commented on his alienation from the rest of the expedition and from the space through which they were travelling, an observation which in itself presupposes a 'here' and a 'there', an ' $\mathrm{I}$ ' and an 'Other'. (At times it becomes even too explicit: "Stanley is an Other. His body is not part of the caravan's body," p. 78.) In the new consciousness, in the new language mined from silence, dichotomies are dissolved and deconstructed in a new experience of oneness and wholeness. Even his "bowel movements are now in phase with the sun and moon" (p. 130):

I was a gas that took on the color of the surroundings: green in the forest, brownish yellow on the savannah, white in the sand dunes, red on red soil. That made me light and porous. I was gazelle and bird. (p. 152.) 
This oneness with the world, which is simultaneously "the final zero, annihilation" (76), is also an accession to femininity: "I am a child about to slide into the moist warm womb of its mother, and I become pregnant with myself (p. 76).

In this dimension, beyond speech, where he writes down "the sound of the wilderness" (p. 146), and where "all that remains is hymn and spectacle, praise song and comedy" (p. 146), Stanley cannot follow him and cannot understand him. The explorer has only conventional explanations: "You have not been up to your task. You have not conquered a continent, it has conquered you" (p. 147) - to which Shaw responds, with deeper meaning than his commander can fathom: "'Yes, I have finally lost myself.' But it wasn't me speaking. It was someone else" (p. 147).

Language, after all, is always 'someone else's', as Atwood, too, has demonstrated so eloquently in Surfacing. ${ }^{11}$

In the last chapter Shaw is no longer with the caravan: Stanley has decided to send him back to Kwihara on his own, into a "wilderness (...) totally silent" (p. 149; cf Stanley, 1872:321). Yet now, "separate from the caravan (...) I live right inside it" (p. 150), and from this inside/outside he re-presents both faithfully (i.e. in terms which can be corroborated from Stanley's journal) and imaginatively everything experienced by the expedition up to, and including, the meeting with Livingstone. The penultimate narrative moment of the text comprises, in fact, a long monologue by Livingstone (p. 167-170).

This marks simultaneously the presence of absence and the absence of presence - the territory of Derrida, of much feminist enquiry, and of much of the postcolonial enterprise.

The end of the novel is a return to the sea and its 'almost inaudible' whales (p. 172): the sea which is now both mother ("the cool gorge where the water rises in a tree of bubbles") and father ("exact descriptions of travel, singing diagrams of temperature"). It is all and nothing: in fact, "Perhaps there never were any whales in Lake Tanganyika. What do I care" (p. 172).

The crucial image, in the text, of the new explorer/implorer, burdened by humanity but not by memory, divested of the language of patriarchy and of the imperium, and invested with the new language of the Beyond and of Africa, is the Bearer: the deaf-mute member of the expedition who neither speaks nor listens, only moves: "The Bearer is not touched by our journey. He is our journey" (p. 106). But total silence is inhuman; language is our condition. And that is why, surrounding the image of the Bearer, the text exists: a text reduced to language, since that is as much as we can bear - but a language which itself is but a system of traces pointing towards the unnameable which (to the explorer) is Africa, and (to man) is woman. 12

11 "Sight flowing ahead of me over the ground, eyes filtering the shapes, the names of things fading but their forms and uses remaining, the animals learned what to eat without nouns." (Atwood, 1983:160.)

12 The extent to which this Africa and this Woman confirm stereotypical (European/male) fantasies is open to further investigation; my concern here is no more than the identification of a textual construct. 


\section{Bibliography}

Ashcroft, Bill et al. 1989. The Empire Writes Back: Theory and Practice in Post-colonial Literature. London \& New York : Routledge.

Atwood, Margaret 1974. Sunival. A Thematic Guide to Canadian Literature. Toronto : Anansi.

Atwood, Margaret 1983 (1972). Surfacing. Toronto : General Publishing Co.

Calvino, Italo 1981. If on a Winter's Night a Traveller. London : Secker \& Warburg.

Cixous, Helène 1981. Castration or Decapitation. Signs, 7(1):41-55.

Conrad, Joseph 1985. (1902): Heart of Darkness. Harmondsworth : Penguin.

De Lauretis, Teresa 1984. Desire in Narrative. In: Alice Doesn't. Houndmills and London : Macmillan.

Eco, Umberto 1979. A Theory of Semiotics. Bloomington : Indiana University Press.

Hagerfors, Lennart 1991. (1985) The Whales in Lake Tanganyika. Harmondsworth : Penguin.

Moi, Toril 1985. Serual/Textual Politics. London \& New York : Routledge.

Spivak, Gayatri Chakravorty 1988. Can the Subaltern Speak? In: Nelson, Cary \& Grossberg, Lawrence (eds.): Maxism and the Interpretation of Culture. London : Macmillan. p. 271-311.

Stanley, Henry M. 1872. How I Found Livingstone. Travels, Adventures and Discoveries in Ceniral Africa. London : Sampson Low, Marston, Low \& Searle (Facsimile edition, Time/Life Books, 1984).

Stockenström, Wilma 1983 (1981). The Expedition to the Baobab Tree. London : Fabcr \& Faber.

\section{University of Cape Town}

